\title{
ANALISIS KEPUASAN PENGGUNA ZOOM CLOUD MEETINGS SEBAGAI MEDIA PEMBELAJARAN MENGGUNAKAN MODEL DELONE \& MCLEAN
}

\author{
Bangbang Supriyadi ${ }^{1}$, Sari Susanti \\ ${ }^{1}$ Universitas Adhirajasa Reswara Sanjaya \\ e-mail: bngbngsupriyadi@gmail.com \\ 2Universitas Adhirajasa Reswara sanjaya \\ e-mail: sarisusanti@ars.ac.id
}

\begin{abstract}
Abstrak
Aplikasi Zoom meeting cloud merupakan layanan konferensi video berbasis cloud computing. aplikasi ini memungkinkan penggunanya bertatap muka dengan pengguna lainnya secara virtual yang telah tergabung sebelumnya. Aplikasi tersebut meningkat penggunanya ditengah pandemic virus yang sedang melanda. Penelitian ini dilakukan untuk menganalisis kepuasan pengguna aplikasi Zoom Meeting Cloud khususnya Mahasiswa Universitas Adhirajasa Reswara Sanjayauntuk malakukan pembelajaran jarak jauh. Penelitian ini menggunakan metode Delone \& McLean menggunakan empat variabel yaitu Kulitas Informasi (Information Quality), Kualitas Sistem (Sistem Quality), Kualitas Layanan (Service Qaulity), Kepuasan Pengguna (User Satisfaction).Pengumpulan data dilakukan dengan cara menyebarkan kuisioner secara online kepada Mahasiswa Universitas Adhirajasa Reswara Sanjayadan mengambil Samplesebanyak 50 responden. Metode pengolahan data yang digunakan adalahRegresi Linear berganda menggunakan SPSS 21. Hasil penelitian ini menunjukan variabel Kulitas Informasi (Information Quality), Kualitas Sistem (Sistem Quality), Kualitas Layanan (Service Qaulity),Kepuasan Pengguna (User Satisfaction).memiliki nilai korelasi sebesar 0,807 terhadap keberhasilan kinerja sistem, artinya variabel independen dan dependen dalam penelitian ini memiliki hubungan yang kuat, nilai $F$ hitung sebesar 28,619 nilai $R$ Square $\left(R^{2}\right)$ sebesar $65,1 \%$, sedangkan sisanya dipengaruhi oleh variabel lain yang tidak dimasukan dalam model ini.Dengan demikian menyatakan bahwa variabel Kualitas Informasi (X1), Kualitas Sistem (X2), dan Kualitas Layanan (X3) secara simultan berpengaruh positif terhadap Kepuasan Pengguna (Y) dapat diterima.
\end{abstract}

Kata Kunci: Sistem Informasi, Analisis Kepuasan, Mahasiswa, Delone \& McLean

\begin{abstract}
Zoom meeting cloud application is a cloud computing-based video conferencing service. This application allows users to face to face with other users who have virtually joined the previous. The application is increasing users amid the pandemic virus that is being hit. This study was conducted to analyze the user satisfaction of the Zoom Meeting Cloud application, especially Ars University Students, for distance learning. This study uses the Delone \& McLean method using four variables, namely Information Quality, System Quality, Service Qaulity, and User Satisfaction. Data collection was carried out by distributing questionnaires online to Ars University Students and taking as many as 50 respondents. Data processing method used is multiple linear regression using SPSS 21. The results of this study indicate the variable Quality of Information (Information Quality), System Quality (Service Quality), Service Quality (Service Qaulity), User Satisfaction (User Satisfaction). has a correlation value of 0.807 to the success of system performance, meaning that the independent and dependent variables in this study have a strong relationship, the calculated $F$ value of $28.619 R$ Square (R2) value of $65.1 \%$, while the rest is influenced by other variables not included in this model. Thus states that the variable Information Quality (X1), System Quality (X2), and Service Quality (X3) simultaneously have a positive effect on User Satisfaction $(Y)$ can be accepted.
\end{abstract}

Keywords: Information Systems, Satisfaction Analysis, Students, Delone \& McLean 


\section{Pendahuluan}

Kegaitan belajar mengajar biasanya dilakukan diruangan kelas secara langsung, sehingga semua orang yang terlibat dalam kegiatan tersebut berkumpul dan berdiskusi secara langsung. Namun saat ini kegaitan pembelajaran dapat didukung dengan tekknologi khususnya aplikasi, yang memungkinkan pengguna nya tidakperlu datang keruangan kelas secara langsung. Teknologi yang digunakan untk melakukan teknologi tersebut adalah Video conference (Azzam et al., 2019) Tidak adanya pembelajaran di Sekolah dan Universitas di tengah pandemic virus membuat penggunna aplikasi video conference menjadi meningkat, salah satunya aplikasi Zoom meeting cluod. Penggunanya meningkat pada 26 Maret 2020, Aplikasi Zoom mencatatkan sebanyak 257,853 pengguna, di mana pada minggu sebelumnya 19 Maret 2020, aplikasi ini berada pada angka 91.030 orang. Di sisi lain, aplikasi posisi Zoom diikuti oleh Skype di posisi kedua yang mencatatkan 71.155 pengguna, dengan indikasi mengalami kenaikan sebesar 8,02 persen kenaikan dari pengguna sebelumnya yang mencapai 65.875 orang. Untuk aplikasi selanjutnya, Hangouts Meet mengalami peningkatan trafik yang cukup signifikan lewat penggunaan di masyarakat pada 19 Maret 2020 mencapai 7.917 yang meningkat pada 26 Maret 2020 sebesar 10.454 pengguna, dengan kenaikan sebesar 32, 14 persen (Hidayatullah et al., 2020).

Melansir dari laman resminya ("Zoom.Us,") Zoom merupakan komunikasi video dengan platform cloud yang mudah dan andal untuk konferensi video dan audio, kolaborasi, obrolan dan webinar diseluruh perangkat seluler, desktop, telepon dan sistem ruangan. Fitur-fitur yang ada didalam aplikasi Zoom antara lain; Audio HD, , Alat kolaborasi bawaan, Keamanan, Rekaman dan Transkip, Fitur penjadwalan, Obrolan Tim.

Meningkatnya penggunaan aplikasi Zoom Meeting Cloud tak bisa lepas terkait dengan system keamanan dari peretas data pribadi. Keamanan di suatu sistem informasi sangat penting karena jika data dan informasi pribadi pengguna bisa diakses oleh orang lain maka tindakkan kejahatan mungkin akan terjadi. Kualitas sistem keamanan menjadi keperluan yang wajib di suatu system informasi karena kepuasan pengguna akan di pengaruhi oleh kualitas system layanan yang baik. tidak sedikit pengguna mengirim kritik dan saran terutama melalui media berita online yang ramai mempertanyakan system keamanan di Zoom meeting Cloud (Yuningsih, 2019)

Penelitian ini akan menguji tingkat kepuasan pengguna aplikasi Zoom meeting cloud sebagai media pembelajaran jarak jauh menggunakan model Delone \& McLean. Dipilihnya model kesusksesan Delone \& McLean, model Delone \& McLean karena memiliki 6 kategori untuk mengukur kesuksesan system informasi, yaitu: kualitas system, kualitas informasi, penggunaan, kepuasan pengguna, kinerja individu, dan kinerja organisasi. Model kesuksesan Delon \& McLean (2003) menambahkan variable kualitas layanan (Tan et al., 2015). Selain itu, model Delone \& McLean mampu digunakan untuk mengukur kesuksesan kualitas system informasi, Menawarkan langkah yang lengkap dan terstruktur dari complexindependent yang saling berhubungan dengan suatu system informasi (Sukajie et al., 2019).

\section{Metode Penelitian}

Pada penelitian kali ini, metode pengumpulan data menggunakan kuisioner atau angket. Kuisioner atau angket merupakan pertanyaan yang telah disusun secara sistematis untuk di isi oleh responden, dan kemudian pertanyaan tersebut di kembalikan ke peneliti.Jenis kuisioner yang digunakan adalah jenis kuisioner tertutup, yaitu kusioner yangtelah disediakan jawabannya sehingga responden tinggal memimilih jawabannya (Mahendra, 2015).

Rumusan Hipotesis yang diuji penelitian ini adalah:

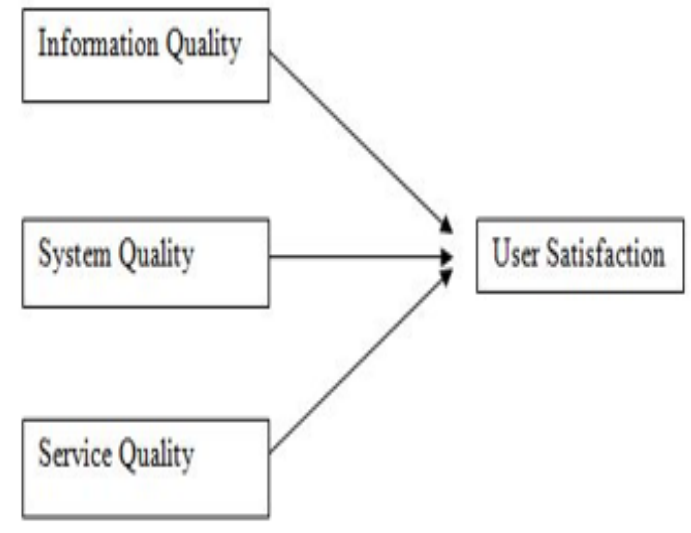

Gambar 1. Kerangka Penelitian

$\mathrm{H} 1$ : Diduga Kualitas Informasi (information quality) berpengaruh signifikan positif tejadap keusan pengguna (user satisfaction) Zoom Meeting Cloud sebagai media pemeelajaran jarak jauh. 
H2: Diduga kualitas system (system quality) berpengaruh signifikan positif terhadap kepuasan pengguna (user satisfaction), Zoom Meeting Cloud sebagai media pembelajaran jarak jauh.

H3: Diduga kaulitas layanan (service quality) berpengaruh signifikan positif terhadap kepuasan pengguna (user satisfaction) Zoom Meeting Cloud sebagai media pembelajaran jarak jauh.

H4: Diduga kualitas informasi (information quality), kualitas system (system quality), kaulitas layanan (service quality) berpengaruh signifikan positif secara bersamaan terhadap kepuasan pengguna (user satisfaction) Zoom Meeting Cloud sebagai media pembelajaran jarak jauh.

Pengggunaan instrument penelitian harus disesuaikan dengan variabel peneltian yang akan diteliti. Instrumen atau alat ukur dalam penelitian ini adalah kuisioner atau angket. Kuisioner atau angket merupakan pertanyaan yang telah disusun secara sistematis untuk di isi oleh responden, dan kemudian pertanyaan tersebut di kembalikan ke peneliti.Jenis kuisioner yang digunakan adalah jenis kuisioner tertutup, yaitu kusioner yang telah disediakan jawabannya sehingga reponden tinggal memilih jawabannya (Mahendra, 2015).

Tabel 1. Pengukuran Skala Linkert

\begin{tabular}{|c|c|c|}
\hline Simbol & Keterangan & Skor \\
\hline SS & Sangat Setuju & 5 \\
\hline S & Setuju & 4 \\
\hline RR & Ragu-ragu & 3 \\
\hline TS & Tidak Setuju & 2 \\
\hline STS & $\begin{array}{c}\text { Sangat Tidak } \\
\text { Setuju }\end{array}$ & 1 \\
\hline
\end{tabular}

Sumber: (Irawan \& Handayani, 2018)

Dalam sebuah penelitian hal sangat penting adalah menentukan populasi dan sampel peneltian. Lebih jelasnya berikut ulasan yang dijelasakan oleh beberapa sumber peneltian :

1. Populasi adalah wilayah generalisasi yang memiliki objek atau subjek sehingga memiliki kualitas dan karakteristik tertentu yang ditelah diterapkan oleh peneliti untuk dipelajari dan mengambil kesimpulan (Yel \& Ningtyas, 2019).

2. Sampel adalah jumlah dan karakristik dari sebagian yang dimiliki oleh populasi tersebut. Apabila populasi yang dimiliki besar dan peneliti tidak sanggup karena adanya keterbatasan mempelajari semua yang ada pada populasi, maka peneliti dapat menggunakan sampel populasi yang diambil dari populasi tersebut (Prasetio et al., 2018).

Tahapan Penelitian yang dilakukan penulis adalah tahapan penelitian deskriptif yang bertujuan untuk membuat secara sistematis, factual dan akurat mengenai fakta-fakta dan sifat-sifat populasi atau daerah tertentu. Tahapan penelitiannya yaitu:

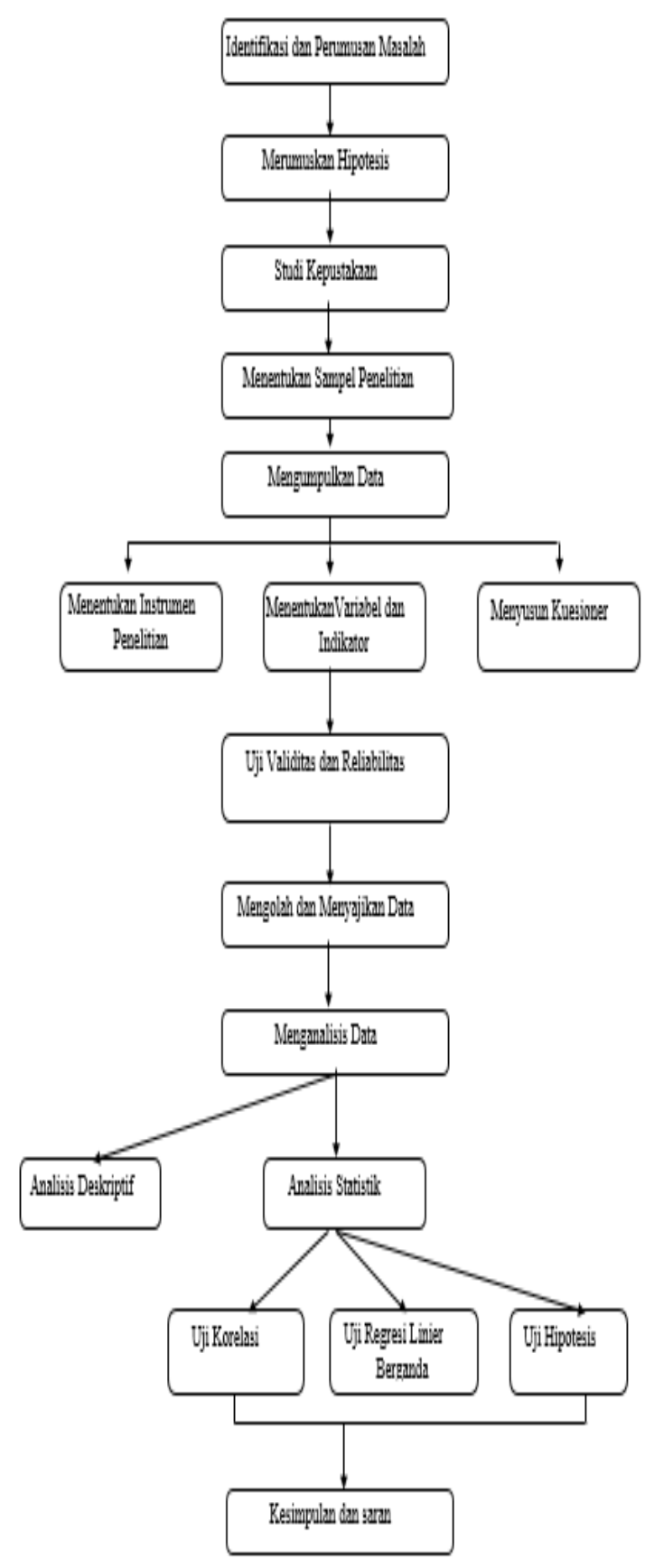

Gambar 2. Tahapan Peneltian 


\section{Hasil dan Pembahasan}

Hasl penelitian merupakan hasil dari perumusan masalah, rumusan hipotesis dan pengumpulan data bedasarkan hasil literature, metode-metode dan analisis data yang dilakukan pada suatu objek penelitian dengan tujuan mencari focus permasalahan yang diteliti sehingga mendapatkan kesmpulan dan pengambilan keputusan yang dpatdibuktikan kebenarannya.

Sebagaimana yang telah disampaikan pada bagian sebelumnya bahwa peneltian ini menggunakan metode survey yaitu menyebarkan kuisioner secara online terhadap pengguna Zoom Meeting Cloud sebagai media pembelajaran jarak jauh sebanyak 50 kuisioner. Berikut gambaran umum secara menyeluruh menganai hasil pengumpulan data responden yang subjek

Tabel 2. Karakteristik Bedasarkan Jurusan

\begin{tabular}{|c|c|c|}
\hline Jurusan & Frekuensi & $\begin{array}{c}\text { Presentase } \\
(\%)\end{array}$ \\
\hline Ekonomi & 9 & $18 \%$ \\
\hline DKV & 4 & $8 \%$ \\
\hline $\begin{array}{c}\text { Ilmu } \\
\text { Komunikasi }\end{array}$ & 3 & $6 \%$ \\
\hline Manajemen & 1 & $2 \%$ \\
\hline Perhotelan & 1 & $2 \%$ \\
\hline $\begin{array}{c}\text { Sistem } \\
\text { Informasi }\end{array}$ & 28 & $56 \%$ \\
\hline $\begin{array}{c}\text { Teknik } \\
\text { Informatika }\end{array}$ & 4 & $8 \%$ \\
\hline Total & 50 & $100 \%$ \\
\hline
\end{tabular}

Dapat dilihat bahwa dari total 50 responden, kelompok responden dari 7 jurusan di Univeristas Ars, diantaranya: Ekonomi (18\%), DKV (8\%), IImu Kominumkasi (6\%), Manajemen (2\%), Perhotelan (2\%), Sistem Informasi (56\%), Teknik Informatika (8\%). Berdasarkan data diatas dapat diketahui bahwa Mahasiswa dari setiap Jurusan di Universitas Adhirajasa Reswara Sanjayayang menggunakan aplikasi Zoom Meeting Cloud sebagai media pembelajaran jarak jauh menunjukan yang lebih dominan adalah Mahasiswa dari Jurusan Sistem Informasi.

Tabel 3. Hasil Skor Kualitas Informasi (Information Quality)

\begin{tabular}{|l|l|l|l|}
\hline Variabel & $\begin{array}{l}\text { Skor } \\
\text { Total } \\
\text { Variabel }\end{array}$ & Variabel & Kategori \\
\hline X1 & 720 & $\begin{array}{l}\text { Kualitas } \\
\text { Informasi }\end{array}$ & Baik \\
\hline
\end{tabular}

Berdasarkan interval skor diatas, skor total variabel Kualitas Informasi (Information Quality) sebesar 720 berada pada interval 680 - 840. Artinya,variabel Kualitas Informasi (Information Quality) dikategorikan "Baik". Hal ini mengindikasikan bahwa variabel Kualitas Informasi (Information Quality) pada Zoom Meeting Cloud direspon positif dan baik oleh pengguna atau responden aplikasi Zoom Meeting Cloud.

Tabel 4. Hasil Skor Kualitas Sistem (Sistem Quality)

\begin{tabular}{|l|l|l|l|}
\hline Variabel & $\begin{array}{l}\text { Skor } \\
\text { Total } \\
\text { Variabel }\end{array}$ & Variabel & Kategori \\
\hline X2 & 791 & $\begin{array}{l}\text { Kualitas } \\
\text { Sistem }\end{array}$ & Baik \\
\hline
\end{tabular}

Berdasarkan interval skor diatas, skor total variabel Kualitas Sistem(System Quality)sebesar 791 berada pada interval 680 - 840Artinya, variabel Kualitas Sistem (Sistem Quality) dikategorikan "Baik". Hal ini mengindikasikan bahwa variabel Kualitas Sistem (System Quality) pada aplikasi Zoom Meeting Cloud direspon positif dan baik oleh pengguna atau responden aplikasoi Zoom Meeting Cloud.

Tabel 5. Hasil Skor Kualitas Layanan (Service Quality)

\begin{tabular}{|l|l|l|l|}
\hline Variabel & $\begin{array}{l}\text { Skor } \\
\text { Total } \\
\text { Variabel }\end{array}$ & Variabel & Kategori \\
\hline X3 & 509 & $\begin{array}{l}\text { Kualitas } \\
\text { Layanan }\end{array}$ & Baik \\
\hline
\end{tabular}

Berdasarkan interval skor diatas, skor total variabel Kualitas Layanan(Service Quality)sebesar 509 berada pada interval 510 - 630. Artinya,variabel Kualitas Layanan (Service Quality)dikategorikan "Baik". Hal ini mengindikasikan bahwa variabel Kualitas Layanan (Service Quality) pada aplikasi Zoom Meeting Clouddirespon positif dan baik oleh pengguna atau responden aplikasi Zoom Meeting Cloud.

Tabel 6. Hasil Skor Kepuasan Pengguna (Uer Satisfaction)

\begin{tabular}{|l|l|l|l|}
\hline Variabel & $\begin{array}{l}\text { Skor } \\
\text { Total } \\
\text { Variabel }\end{array}$ & Variabel & Kategori \\
\hline Y & 697 & $\begin{array}{l}\text { Kepuasan } \\
\text { Pengguna }\end{array}$ & Baik \\
\hline
\end{tabular}


Berdasarkan interval skor diatas, skor total variabel Kepuasan Pengguna(User Satisfaction)sebesar 697 berada pada interval 680 - 840. Artinya, variabel Kepuasan Pengguna (User Satisfaction) dikategorikan "Baik". Hal ini mengindikasikan bahwa variabel Kepuasan Pengguna (User Satisfaction) pada aplikasi Zoom Meeting Clouddirespon positif dan baik oleh pengguna atau responden aplikasi Zoom Meeting Cloud.

\section{a. Uji Validitas}

Pada Uji Validitas pada variabel X1 (Kualitas System), X2 (Kualitas Informasi), X3 (Kualitas Layanan), X4 (Pemakaian) dan $Y$ (Kepuasan Pemakai) sebagai beriku di tujukan pada $r$ hitung:

Tabel 7. Uji Validasi

\begin{tabular}{|l|l|l|l|}
\hline $\begin{array}{l}\text { No. } \\
\text { Instru } \\
\text { men }\end{array}$ & $\begin{array}{l}\text { r } \\
\text { hitung }\end{array}$ & $\begin{array}{l}\text { R tabel } \\
\% \%\end{array}$ & Keterangan \\
\hline 1 & 0,903 & 0,279 & Valid \\
\hline 2 & 0,803 & 0,279 & Valid \\
\hline 3 & 0,808 & 0,279 & Valid \\
\hline 4 & 0,775 & 0,279 & Valid \\
\hline 5 & 0,897 & 0,279 & Valid \\
\hline 6 & 0,871 & 0,279 & Valid \\
\hline 7 & 0,750 & 0,279 & Valid \\
\hline 8 & 0,862 & 0,279 & Valid \\
\hline 9 & 0,890 & 0,279 & Valid \\
\hline 10 & 0,897 & 0,279 & Valid \\
\hline 11 & 0,853 & 0,279 & Valid \\
\hline 12 & 0,879 & 0,279 & Valid \\
\hline 13 & 0,839 & 0,279 & Valid \\
\hline 14 & 0,836 & 0,279 & Valid \\
\hline 15 & 0,885 & 0,279 & Valid \\
\hline
\end{tabular}

Dari total 15 pertanyaan, hasil pengolahan uji validitas di atas tidak ditemukan item pertanyaan yang tidak valid, karena rata-rata nilai $r$ yang muncul terhitung lebih besar daripada nilai $r$ tabel $(>0,279)$. Dengan melakukan pengujian Validitas, terbukti bahwa kuesioner atau angket yang digunakan dalam penelitian ini semuanya valid dan layak digunakan untuk pengambilan data dalam penelitian ini.

\section{b. Uji Reliabilitas}

Tabel 8. Uji Reliabilitas

\begin{tabular}{|l|l|l|}
\hline Variabel & $\begin{array}{l}\text { Cronbach's } \\
\text { Alpha }\end{array}$ & Keterangan \\
\hline $\begin{array}{l}\text { Kualitas } \\
\text { Informasi } \\
(\mathrm{X} 1)\end{array}$ & 0,833 & Reliabel \\
\hline
\end{tabular}

\begin{tabular}{|l|l|l|}
\hline $\begin{array}{l}\text { Kualitas } \\
\text { Sistem } \\
(\mathrm{X} 2)\end{array}$ & 0,866 & Reliabel \\
\hline $\begin{array}{l}\text { Kualitas } \\
\text { layanan } \\
\text { (X3) }\end{array}$ & 0,846 & Reliabel \\
\hline $\begin{array}{l}\text { Kepuasaan } \\
\text { Pengguna }\end{array}$ & 0,882 & Reliabel \\
\hline
\end{tabular}

Hasil uji realibilitas diatas menunjukan bahwa semua variabel mempunyai koefisien Cronbach's alpha yang lebih besar dari nilai $r$ tabel yaitu 0,279 sehingga dapat dikatakan semua konsep pengukur masing-masing variabel dari kuesioner adalah reliabel yang berarti bahwa kuesioner yang digunakan dalam penelitian ini merupakan kuesioner yang handal dan konsisten sehingga bisa digunakan berkalikali.

\section{c. Uji Normalitas}

Uji normalitas adalah untuk mengetahui apakah nilai data residual terdistribusi secara normal atau tidak. Model regresi yang baik adalah yang memiliki nilai residual yang terdistribusi secara normal.

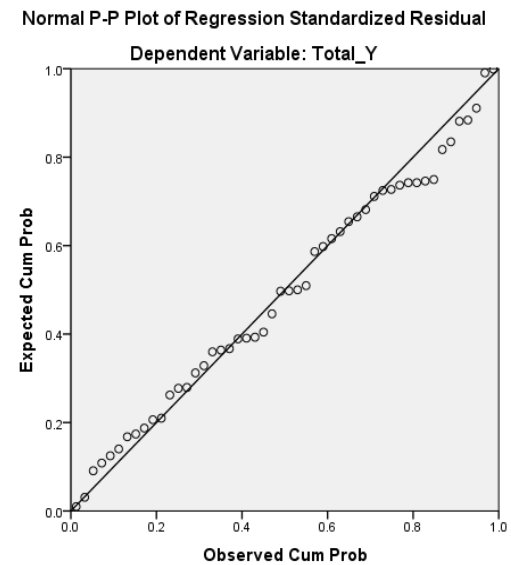

Gambar 3. Grafik Normal P-P Plot

Dari grafik tersebut dapat diketahui bahwa titik-titik meyebar sekitar garis dan mengikuti garis diagonal maka nilai residual tersebut dikatakan normal.

\section{d. Uji Heteroskedastisitas}

Heteroskedastisitas merupakan indikasi varian antar residual tidak homogen yang mengakibatkan nilai taksiran yang diperoleh tidak lagi efisien. Situasi heteroskedaktisitas akan menyebabkan penaksiran keofisienkoefisien regresi menjadi tidak efisien dan hasil taksiran dapat menjadi kurang atau 
melebihi dari yang semestisnya. Ada salah satu metode untuk bisa menguji Heteroskedastisitas, metode tersebut grafik scratterplot. grafik scratterplot adalah grafik untuk mengamati mengetahui terjadinya heteroskedasrisitas. Apabila tidak ada pola yang jelas, serta memperlihatkan titik-titik yang menyebar diatas dan di bawah di sumbu $\mathrm{Y}$, maka bebas dari heteroskedasrisitas. Berikut disajikan grafik heteroskedaktisitas

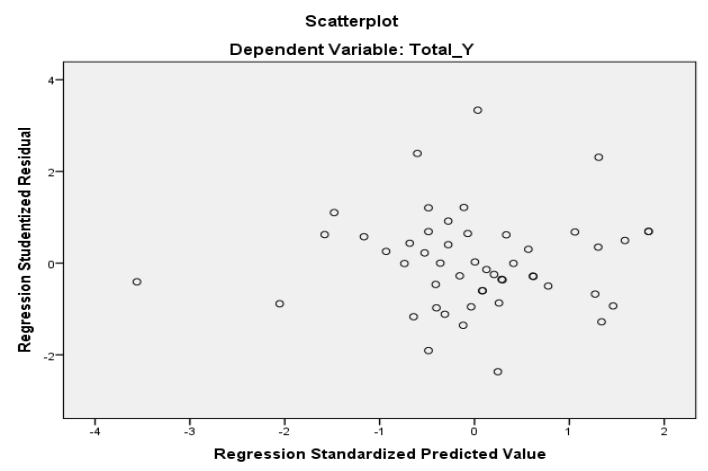

Gambar 4. Grafik Heteroskedaktisitas

\section{Kesimpulan}

Bedasarkan penelitian yangtelah dilakukan kepada pengguna aplikasi Zoom Meeting Cloud pada mhasiswa Universitas Adhirajasa Reswara Sanjayasebagai media pembelajaran jarak jauh dengan menggunakan model kesuksesan system informasi Delone \& McLean, maka dapat ditarik kesimpulan sebagai berkut:

1. variabel Kualitas Informasi (X1) berpengaruh positif terhadap Kepuasan pengguna $(Y)$ dapat diterima.

2. Kualitas Sistem (X2) berpengaruh positif terhadap Kepuasan Pengguna (Y) dapat diterima.

3. Kualitas Layanan (X3) berpengaruh positif terhadap Kepuasan Pengguna (Y) dapat diterima.

4. variabel Kualitas Informasi (X1), Kualitas Sistem (X2), dan Kualitas Layanan (X3) secara simultan berpengaruh positif terhadap Kepuasan

\section{Saran} Pengguna $(Y)$ dapat diterima.

Berdasarkan hasil penelitian, maka saransaran yang peneliti ajukan sebagai berikut:

1. Hasil penelitian ini dapat dikembangkan pada penelitian selanjutnya dengan penambahan jumlah sampel dan memodifikasi indikator.

2. Penelitian ini dapat dikembangan pada penelitian selanjutnya dengan penambahan jumlah variabel yang akan diuji.

3. Selanjutnya penelitian ini dapat di kembangkan lagi dengan menggunakan model pendekatan selain model Kesuksesan Sistem Informasi DeLone dan McLean, seperti TAM, UTAUT dan lain sebagainya.

4. Untuk penelitian selanjutnya yang menggunakan model yang sama yaitu model Delone dan Mclean bisa meneliti obyek yang berbeda terkait Video Confrence,seperti Google Hangout. Skype, WeBex dan lain sebagainya.

\section{Refrensi}

Azzam, F. N., Kartikasari, D. P., \& Bakhtiar, F. A. (2019). Implementasi Video Conference dengan File Sharing menggunakan WebRTC. 8.

DeLone, W. H., \& McLean, E. R. (2003). The Delone And Mclean Model Of Information Systems Success: A Ten-Year Update. Journal Of Management Information Systems, 19(4), 9-30.

Hidayatullah, S., Khouroh, U., Windhyastiti, I., Patalo, R. G., \& Waris, A. (2020). Implementasi Model Kesuksesan Sistem Informasi DeLone And McLean Terhadap Sistem Pembelajaran Berbasis Aplikasi Zoom Di Saat Pandemi Covid-19. Jurnal Teknologi Dan Manajemen Informatika, 6(1), 45-53. https://doi.org/10.26905/jtmi.v6i1.41 65

Irawan, R., \& Handayani, H. (2018). Pengaruh Disiplin Terhadap Kinerja Karyawan Pada Pt Relasi Abadi Jakarta. Widya Cipta: Jurnal Sekretari Dan Manajemen, 2(1), 1-7. Mahendra, I. (2015). Analisa Penerimaan Pengguna Sistem Informasi Koperasi Pada Koperasi Karyawan Budi Setia Jakarta Dengan Technology Acceptance Model. Jurnal Pilar Nusa Mandiri, 11(1), 7080.

Prasetio, R. T., Ramdhani, Y., Anshori, I. F., Rismayadi, A. A., Hidayatulloh, S., \& Mubarok, A. (2018). Analisis Penerimaan Microsoft Office dengan Pendekatan Technology Acceptance Model pada Warga Desa Karyamukti Kecamatan Cililin. Jurnal Abdimas BSI: Jurnal Pengabdian Kepada Masyarakat, 1(3), Article 3. 
https://doi.org/10.31294/jabdimas.v1 i3.4142

Sukajie, B., Laksono, F. A., Mubarok, A., Susanti, S., \& Kurniawan, A. (2019). Analisis Kepuasan Pengguna Youtube Sebagai Media Pendidikan Menggunakan Model DeLone Dan McLean. Jurnal Responsif: Riset Sains \& Informatika, 1(1), 46-52.

Tan, D., Suyatno, S., \& Aliyah, S. (2015). Pengujian Kesuksesan Sistem Informasi Model Delone \& Mclean Pada Sektor Publik. http://publikasiilmiah.ums.ac.id/hand le/11617/5130

Yel, M. B., \& Ningtyas, S. A. (2019). Implementasi Model Utaut Untuk Analisis Faktor Yang Memengaruhi Minat Pemanfaatan Dan Perilaku Penggunaan Sistem Informasi. Journal of Information System, Applied, Management, Accounting and Research, 3(2), 26-38.

Yuningsih, Y. (2019). Metode Delone dan Mclean Dalam Kepuasan Konsumen Terhadap Aplikasi Shopee. Bina Insani lct Journal, 6(1), 55-64.

Zoom.us. (n.d.). Retrieved August 12, 2020, from https://zoom.us/ 